\title{
Establishment of a Type Specimen Collection at the Alaska State Geologic Material Center
}

Contributed by Robert L. Ravn, IRF Group

GMC467

The GMC data archive provides analytical and interpretive data resulting from testing by third parties on material borrowed from samples housed at the Alaska Geologic Materials Center. These files are

produced by the third-party agency or company that conducted the sampling and analysis. The results and interpretations have not undergone technical review and should not be cited as reviewed data or as an authoritative information source. Any use of trade names should not be considered an endorsement by DGGS or the State of Alaska.

2020

State of Alaska

Department of Natural Resources

Division of Geological \& Geophysical Surveys

GEOLOGIC MATERIALS CENTER
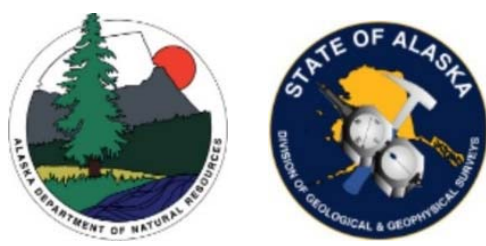


\section{ESTABLISHMENT OF A TYPE SPECIMEN COLLECTION AT THE ALASKA STATE GEOLOGIC MATERIALS CENTER}

Publication of new genera and species for fossil material is governed by a number of important rules, in order to ensure taxonomic rigor and validity. Principal among these are the designation of a single "holotype" specimen to represent the new taxon, and placement of that specimen in a properly curated facility to be held in permanent custody for the purpose of possible future re-examination. As of November 2019, the Geologic Materials Center has established the first such collection of holotype specimens for fossil materials.

Ten such holotypes of palynological specimens described in papers by Ravn (2017) and Ravn and Goodman (2017) have now been placed in the collection, with anticipation that many more fossils, of various kinds, will likewise be curated similarly in the future.

The ten new holotypes, all remains of microscopic marine algae from the North Slope region of Alaska, are illustrated below:

\section{DGGS Palynology Holotypes}

Fromea nohrhansenii Ravn 2017

Fromea quasitabulata Ravn 2017

Fromea gordonwoodii Ravn 2017

Fromea xantha Ravn 2017

Paranelsoniella woodii Ravn \& Goodman 2017

Paranelsoniella minuta Ravn \& Goodman 2017

Cyclopsiella mickeyi Ravn 2017

Xanthocysta ovata Ravn \& Goodman 2017

Wallodinium contortum Ravn 2017

Fromea polaris Ravn 2017

\section{Well and depth}

Natchiq 1 5790-5880

Walakpa 12112.6

Nigliq $17950-7980$

Kalubik 3 6750-6780

Kup River State 17260-

7290

Long Island $17740-7750$

Narvaq 1-5040-5070

Kalubik $34440-4530$

Wolfbutton 32-7-8 6100

North Star 39536
England Finder Coords

$\mathrm{O} 8$

G22/ 4

$\mathrm{Z} 27 / 4$

U37/ 1

$\mathrm{L} 27 / 2$

$\mathrm{Z} 45 / 2$

W35/ 4

Q34/3

$\mathrm{T} 24 / 3$

$\mathrm{J} 40 / 1$ 


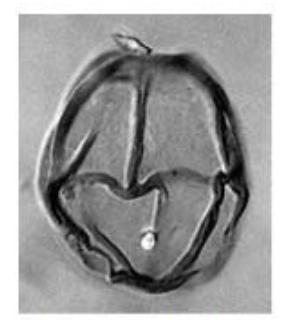

Fremea quasitabulata Ravn 2017 Oxfordian (Upper Jurassic)

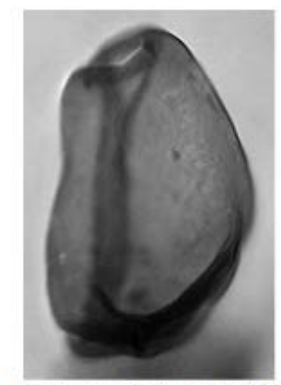

Fremea polaris Ravn 2017 Hauterivian (Lower Cretaceous)

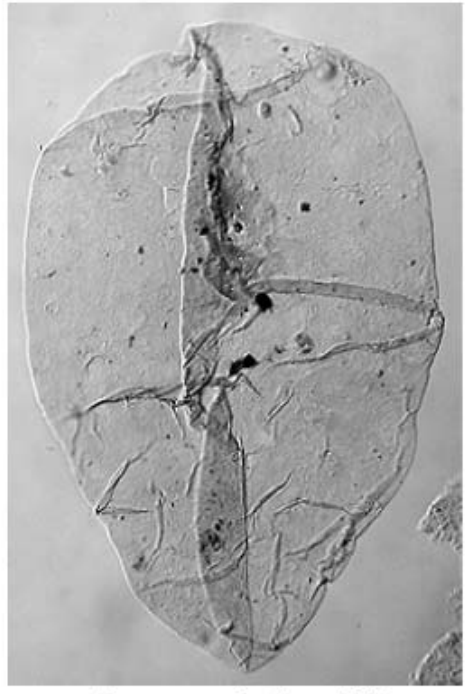

Fremea xantha Ravn 2017 Barremian (Lower Cretaceous)

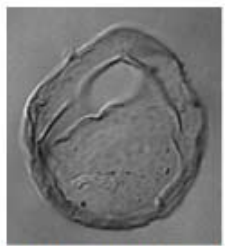

Cyclopsiella mickeyi Ravn 2017 Santonian (Upper Cretaceous)

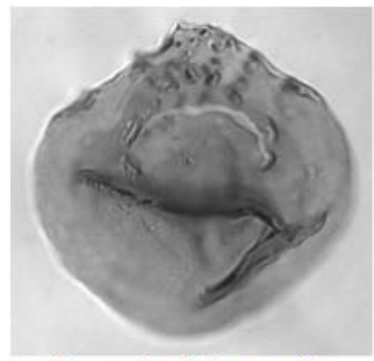

Paranelsoniella woodii

Ravn \& Goodman 2017 Turoniann (Upper Cretaceous)

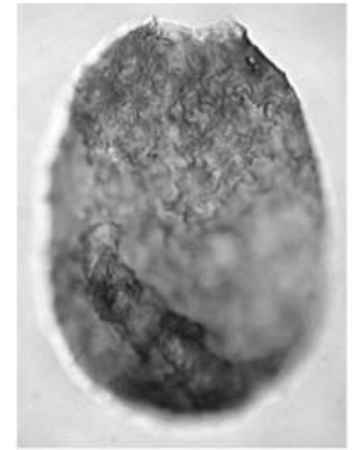

Fremea gordonwoodii Ravn 2017 Toarcian (Lower Jurassic)

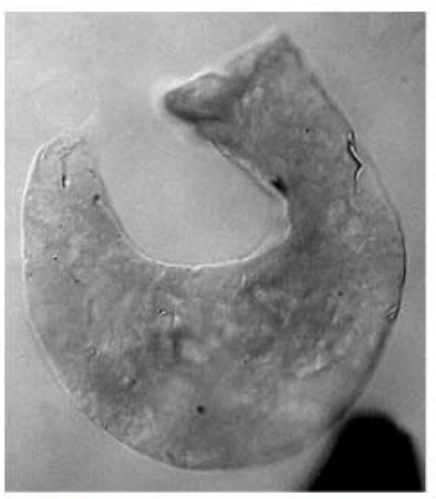

Wallodinium contortum Ravn 2017 Albian (Lower Cretaceous)

\section{$50 \mu \mathrm{m}$}

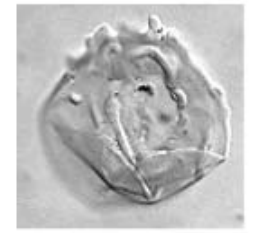

Paranelsoniella minuta

Ravn \& Goodman 2017 Turoniann (Upper Cretaceous)

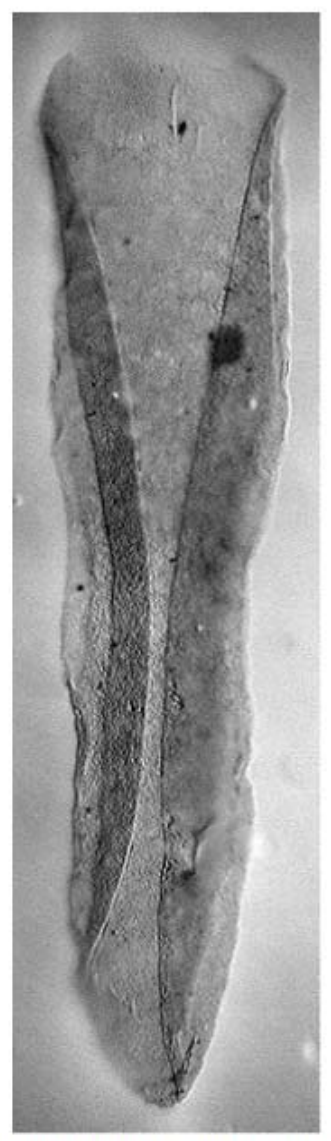

Fremea nohrhansenii Ravn 2017 Alban (Lower Cretaceous)

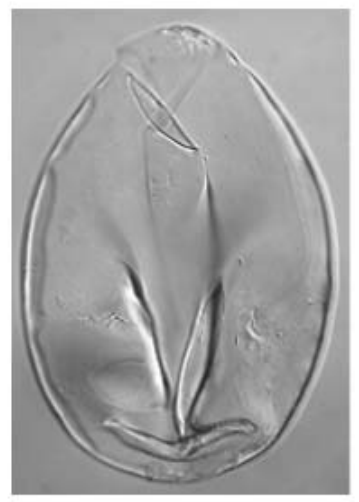

Xanthocysta ovata

Ravn \& Goodman 2017 Cenomanian (Upper Cretaceous) 


\section{REFERENCES}

Ravn RL 2017. The species of Fromea revisited, with comments on selected morphologically similar genera. Palynology 42: 247-261.

Ravn RL, Goodman DK. 2017. Two new marine cyst genera from Upper Cretaceous megasequence strata in the North Slope of Alaska. Palynology 42:271-277. 